\title{
EFEKTIFITAS LEMBAR KERJA PESERTA DIDIK BERBASIS REALISTIC MATHEMATICS EDUCATION DAN PENDIDIKAN KARAKTER PADA MATERI BANGUN RUANG SISI DATAR
}

\author{
Seli Belyuni ${ }^{1}$, Della Maulidiya ${ }^{2}$, Agus Susanta $^{3}$ \\ ${ }^{1,2,3}$ Program Studi Pendidikan Matematika FKIP, Universitas Bengkulu \\ email : ${ }^{1}$ seli.belyuni96@gmail.com, ${ }^{2}$ della.maulidiya@unib.ac.id, ${ }^{3}$ agusunib@yahoo.com
}

\begin{abstract}
Abstrak
Tujuan dari penelitian ini untuk menghasilkan lembar kerja peserta didik berbasis realistic mathematics education dan pendidikan karakter pada materi bangun ruang sisi datar yang memenuhi kriteria efektif. Penelitian ini adalah penelitian pengembangan (Research and Development) dengan mengadopsi prosedur ADDIE yaitu analisis (analysis), perancangan (design), pengembangan (development), implementasi (implementation) dan evaluasi (evaluation). Efektifitas LKPD diujicobakan kepada 28 orang peserta didik kelas VIII E SMP N 15 Kota Bengkulu. Hasil penelitian menunjukkan bahwa LKPD termasuk dalam kategori sangat efektif dengan skor rata-rata 4,25 dengan pencapaian efektifitas : (1) aktivitas peserta didik dengan skor rata-rata 4,48; (2) aktivitas pendidik dengan skor rata-rata 4,71; (3) respon peserta didik dengan skor rata-rata 4,23; (4) hasil belajar peserta didik dengan skor rata-rata 4,18 dan presentase ketuntasan minimal 85,71\%.
\end{abstract}

Kata kunci : Efektifitas, Lembar Kerja Peserta didik (LKPD), Realistic Mathematics Education, Pendidikan Karakter

\begin{abstract}
This research aims to produce student worksheet based on realistic mathematics education and character education on polyhedron material that is effective. This research was a developmental research (Research and Development) by adopting ADDIE procedure which are analysis, design, development, implementation, and evaluation. The effectiveness of LKPD was tested on twenty eight students of class VIII E. The result showed that Student Worksheet based on Realistic Mathematics Education and Character Education on polyhedron material for junior high school grade VIII was very effective with an average score 4,25 with achievement of effectiveness : (1) activity of students with an average score 4,48; (2) activity of teacher with an average score 4,71; (3) the response of students with an average score 4,23; (4) the learning outcomes of students effective with an average score 4,18 and a minimum percentage of $85,71 \%$ mastery.
\end{abstract}

Keywords : Effectiveness, Student Worksheet (LKPD), Realistic Mathematics Education, Character Education

\section{PENDAHULUAN}

Ruseffendi dalam Heruman (2010 : 1) mengungkapkan bahwa matematika adalah bahasa simbol; ilmu deduktif; ilmu tentang pola keteraturan, dan struktur yang terorganisasi, mulai dari unsur yang tidak didefinisikan, ke unsur yang didefinisikan, ke aksioma atau postulat, dan akhirnya ke dalil. Matematika digunakan untuk menganalisa dan menyelesaikan berbagai masalah, khususnya masalah yang berkaitan dengan kehidupan sehari-hari. Matematika yang idealnya merupakan mata pelajaran yang logis dan bermanfaat, justru kurang disenangi oleh peserta didik. Akibatnya, prestasi dan hasil belajar peserta didik pada pelajaran matematika tergolong rendah.

Berbagai upaya terus dilakukan untuk meningkatkan prestasi belajar peserta didik khususnya dalam mata pelajaran matematika. Guru dituntut untuk dapat berinovasi dalam meningkatkan pembelajaran yang dapat mendorong peserta didik untuk belajar lebih optimal, serta harus mampu menguasai dan

Selli, Della, Agus

Efektifitas Lembar Kerja Peserta Didik Berbasis Realistic Mathematics Education dan Pendidikan

Karakter Pada Materi Bangun Ruang Sisi Datar 
mengembangkan bahan ajar yang digunakan yang sesuai dengan kebutuhan dan kemampuan peserta didik demi tercapainya tujuan pendidikan.

Salah satu bentuk bahan ajar adalah Lembar Kerja Peserta Didik (LKPD). LKPD merupakan istilah pembaharuan dari LKS (Lembar Kerja Siswa) yang ada pada kurikulum 2006. Prastowo (2015 : 204) mengartikan LKPD sebagai bahan ajar cetak yang berupa lembaran-lembaran yang berisi tugas, materi, ringkasan dan petunjuk yang harus dilakukan peserta didik. Dalam hal ini tugas-tugas tersebut sudah disesuaikan dengan kompetensi yang harus dicapai. Berdasarkan uraian tersebut, maka LKPD dapat dijadikan pedoman agar peserta didik dapat melakukan kegiatan secara aktif dan mandiri dalam pembelajaran serta membantu mengarahkan peserta didik untuk mengkostruksi pengetahuan yang telah dipelajari untuk menyelesaikan suatu masalah.

Salah satu pendekatan yang cocok untuk pembelajaran matematika adalah pendekatan Realistic Mathematics Education (RME) atau Pendidikan Matematika Realistik (PMR). Suatu ilmu pengetahuan akan bermakna bagi pembelajar jika proses belajar melibatkan masalah sehari-hari. Pendekatan ini didasarkan pada anggapan Hans Freudenthal "Mathematics is a human activity and must be connected to reality" (Nugroho, Riyadi, \& Yulianti, 2014). Matematika harus terkait dengan kenyataan, dekat dengan pengalaman/dunia anak dan relevan dengan kehidupan nyata sehari-hari bagi masyarakat. Salah satu dari lima prinsip RME yang menekankan pada interaksi sosial adalah prinsip interaktivitas (interactivity).

Kurikulum yang berkembang saat ini adalah kurikulum 2013 yang didalamnya terdapat empat kompetensi inti. Salah satu dari empat kompetensi inti memuat tentang pendidikan karakter yaitu menghargai dan menghayati perilaku jujur, disiplin, tanggung jawab, peduli (toleransi, gotongroyong), santun, percaya diri, dalam berinteraksi secara efektif dengan lingkungan sosial dan alam dalam jangkauan pergaulan dan keberadaanya. Karakter yang dimiliki anak dapat menentukan hasil belajarnya, dimana jika seorang anak memiliki karakter sering ribut dikelas, sering mencontek tugas temannya, kurangnya rasa percaya diri dalam mengerjakan tugas dan tidak adanya rasa tanggung jawab dalam mengerjakan soal-soal yang diberikan guru maka akan mengakibatkan rendahnya hasil belajar peserta didik. Oleh karena itu, diperlukan bahan ajar yang dapat menanamkan pendidikan karakter berupa nilai-nilai kebenaran, yaitu hakikat baik dan buruk.

Pemaparan di atas mendorong peneliti untuk mencoba melakukan pengembangan lembar kerja peserta didik berbasis realistic mathematics education dan pendidikan karakter pada materi bangun ruang sisi datar yang memenuhi kriteria efektif.

\section{METODE}

Penelitian ini menggunakan jenis penelitian pengembangan. Penelitian pengembangan (Research and Development) adalah suatu proses yang dipakai untuk mengembangkan dan memvalidasi produk pendidikan (Setyosari, 2013 : 277). Produk yang dikembangkan adalah LKPD berbasis Realistic Mathematics Education (RME) dan pendidikan karakter pada pokok bahasan bangun ruang sisi datar. Subjek dalam penelitian ini adalah siswa/i SMP Negeri 15 Kota Bengkulu kelas VIII E dengan jumlah siswa/i 28 orang terdiri dari 17 orang laki-laki dan 11 orang perempuan.

Model penelitian pengembangan yang digunakan adalah model pengembangan ADDIE yang meliputi tahap analysis (analisis), design (perancangan), development (pengembangan), (implementasi), (evaluasi).Branch (2009:2) menggambarkan langkah-langkah pengembangan media pembelajaran dengan model ADDIE sebagai berikut : 


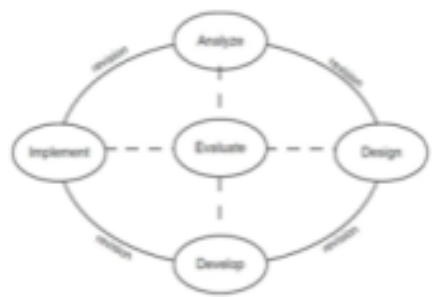

Gambar 1. Langkah-langkah pengembangan model ADDIE

Pribadi (2014) menyatakan model pengembangan ADDIE terdiri dari lima tahap, yaitu :

1. Tahap Analysis (Analisis)

Tujuan analisis adalah untuk mengidentifikasi awal keadaan di sekolah terkait perlunya pengembangan bahan ajar dan menganalisis kelayakan dan syarat-syarat pengembangan. Pada tahap ini hal-hal yang perlu untuk dianalisis antara lain : analisis kebutuhan, analisis kurikulum, dan analisis karakteristik peserta didik

2. Tahap Design (Perancangan)

Pada tahap ini mulai dirancang LKPD yang akan dikembangkan sesuai hasil analisis yang telah dilakukan. Kegiatan yang dilaksanakan pada tahap ini yaitu pemilihan format dan perancangan awal LKPD. Pemilihan format dan bagian LKPD disesuaikan dengan analisis kurikulum, kompetensi dasar, pendekatan realistic mathematics education, dan pendidikan karakter.

3. Tahap Development (Pengembangan)

Tahap pengembangan merupakan tahap realisasi produk. Pada tahap ini, pengembangan LKPD dilakukan sesuai rancangan yang telah dibuat.

4. Tahap Implementation (Implementasi)

Tahap implementasi merupakan langkah realisasi dari tahap perancangan dan pengembangan. Pada tahap ini, peneliti mengimplementasikan hal yang terkait dengan pengembangan LKPD yaitu mengujicobakan LKPD yang dikembangkan dalam kegiatan pembelajaran matematika di sekolah yang akan dilakukan penelitian. Pada tahap ini, dilakukan uji terhadap keefektifan LKPD. Data keefektifan didapat dari lembar aktivitas pendidik, lembar aktivitas peserta didik, angket respon peserta didik dan nilai tes hasil belajar peserta didik.

5. Tahap Evaluation (Evaluasi)

Pada tahap evaluasi, peneliti mengevaluasi hal yang terkait dengan pengembangan LKPD antara lain : a) Melakukan revisi akhir setelah LKPD yang dikembangkan diimplementasikan dalam pembelajaran matematika berdasarkan masukan yang didapatkan dari angket respon atau catatan lapangan pada lembar observasi, dan b) Menghasilkan produk akhir yang layak digunakan dalam pembelajaran matematika di sekolah.

Prosedur penelitian disajikan pada diagram alur berikut.

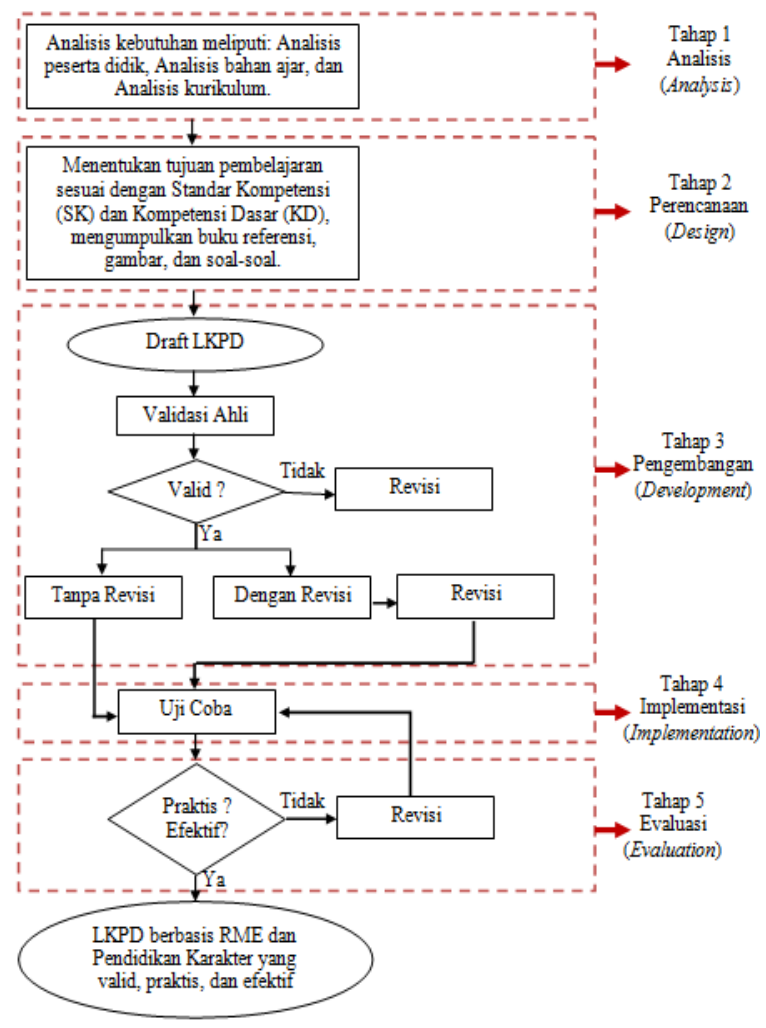

Gambar 2. Diagram alir model pengembangan ADDIE

Instrumen penelitian yang digunakan pada penelitian ini adalah lembar efektifitas LKPD. Instrumen ini digunakan untuk memperoleh data tingkat keefektifan LKPD yang dikembangkan. Instrumen efektifitas ini terdiri dari lembar pengamatan aktivitas peserta didik, 
lembar pengamatan aktivitas pendidik, lembar angket respon peserta didik, dan lembar tes hasil belajar.

Teknik pengumpulan data pada penelitian ini diperoleh dari lembar pengamatan aktivitas peserta didik dan pendidik pada saat proses pembelajaran, lembar angket respon peserta didik, dan lembar hasil belajar peserta didik.

Teknik analisis data yang digunakan dalam penelitian ini sebagai berikut.

\section{Aktivitas Peserta didik}

Lembar penilaian aktivitas peserta didik diisi oleh pengamat. Skor untuk setiap item pada lembar aktivitas peserta didik adalah : 1) sangat tidak setuju, 2) tidak setuju, 3) cukup setuju, 4) setuju, 5) sangat setuju. Rata-rata skor total yang diberikan oleh pengamat dari lembar aktivitas peserta didik dicari dengan menggunakan rumus berikut :

$$
\overline{A P D i}=\frac{\sum_{j=1}^{n} A P D i}{n}
$$

(Rumus Rata-rata Hitung Dimodifikasi dari Sudjana, 2005)

Keterangan :

$\overline{A P D i}$ : Rata-rata skor aktivitas peserta didik dari pengamat ke-i

$A P D i$ : Skor aktivitas peserta didik pertemuan ke-j oleh pengamat ke-i

$n \quad$ : Banyaknya pertemuan

2. Lembar Aktivitas Pendidik

Lembar penilaian aktivitas pendidik diisi oleh pengamat. Skor untuk setiap item pada lembar aktivitas pendidik adalah : 1) sangat tidak setuju, 2) tidak setuju, 3) cukup setuju, 4) setuju, 5) sangat setuju. Rata-rata skor total yang diberikan oleh pengamat dari lembar aktivitas pendidik dicari dengan menggunakan rumus berikut :

$$
\overline{A P i}=\frac{\sum_{j=1}^{n} A P i}{n}
$$

(Rumus Rata-rata Hitung Dimodifikasi dari Sudjana, 2005)

Keterangan :

$\overline{A P i}$ : Rata-rata skor aktivitas pendidik dari pengamat ke-i

$A P i$ : Skor aktivitas pendidik pertemuan ke-j oleh pengamat ke-i

$n$ : Banyaknya pertemuan

\section{Angket Respon Peserta Didik}

Penilaian respon peserta didik dilakukan dengan mengisi respon berdasarkan kegiatan pembelajaran dengan menggunakan LKPD berbasis realistic mathematics education dan pendidikan karakter. Skor untuk setiap item pada lembar respon peserta didik adalah : 1) sangat tidak setuju, 2) tidak setuju, 3) cukup setuju, 4) setuju, 5) sangat setuju. Rata-rata skor total yang diberikan oleh peserta didik dari lembar respon peserta didik dicari dengan menggunakan rumus berikut.

$$
\bar{R}=\frac{\sum_{i=1}^{n} \bar{R}}{i} n
$$

(Rumus Rata-rata Hitung Dimodifikasi dari Sudjana, 2005)

Keterangan :

$\bar{R} \quad$ : Skor rata-rata respon peserta didik

$\bar{R}_{i} \quad$ : Skor rata-rata respon peserta didik ke-i

$n$ : Banyaknya peserta didik

4. Hasil Belajar Peserta didik

Nilai hasil belajar peserta didik diperoleh dari $70 \%$ nilai Tes Hasil Belajar (THB) dan $30 \%$ nilai pengerjaan LKPD, kemudian hasil belajar peserta didik tersebut dibandingkan dengan batas KKM yang berlaku di SMP N 15 Kota Bengkulu khususnya untuk mata pelajaran Matematika yaitu 70.

Persentase ketuntasan belajar klasikal dihitung dengan menggunakan rumus sebagai berikut :

$$
K B=\frac{\sum x}{n} \times 100 \%
$$

Keterangan :

$K B=$ ketuntasan belajar klasikal

$\sum x=$ banyak peserta didik yang tuntas

$n \quad=$ banyak peserta didik

Pemberian skor hasil belajar dapat dilihat pada tabel berikut.

Tabel 1. Kriteria Penilaian Kecakapan Akademik

\begin{tabular}{|c|c|c|}
\hline $\begin{array}{c}\text { Rentang Persentase } \\
\text { Ketuntasan }\end{array}$ & Skor & $\begin{array}{c}\text { Keterangan } \\
\text { Skor }\end{array}$ \\
\hline $\begin{array}{c}\text { Persentase Ketuntasan } \\
>80\end{array}$ & 5 & Sangat Baik \\
\hline $\begin{array}{c}60<\text { Persentase } \\
\text { Ketuntasan } \leq 80\end{array}$ & 4 & Baik \\
\hline $\begin{array}{c}40<\text { Persentase } \\
\text { Ketuntasan } \leq 60\end{array}$ & 3 & Cukup \\
\hline
\end{tabular}




\begin{tabular}{|c|c|c|}
\hline $\begin{array}{c}\text { Rentang Persentase } \\
\text { Ketuntasan }\end{array}$ & Skor & $\begin{array}{c}\text { Keterangan } \\
\text { Skor }\end{array}$ \\
\hline $\begin{array}{c}20<\text { Persentase } \\
\text { Ketuntasan } \leq 40\end{array}$ & 2 & Kurang \\
\hline $\begin{array}{c}\text { Persentase Ketuntasan } \\
\leq 20\end{array}$ & 1 & $\begin{array}{c}\text { Sangat } \\
\text { Kurang }\end{array}$ \\
\hline Pemberian nilai rata-rata efektifitas
\end{tabular}
digunakan rumus :

$$
\bar{E}=\frac{(\overline{A P D} \times 15 \%)+(\overline{A P} \times 15 \%)+(\bar{R} \times 30 \%)+(\bar{H} \times 40 \%)}{100 \%}
$$

Keterangan :

$\bar{E} \quad$ : Skor rata-rata efektivitas

$\overline{A P D}$ :Skor rata-rata hasil aktivitas peserta didik

$\overline{A P} \quad$ :Skor rata-rata hasil aktivitas pendidik

$\bar{R} \quad$ : Skor rata-rata respon peserta didik

$\bar{H} \quad$ : Skor rata-rata hasil belajar peserta didik

Hasil dari skor rata-rata efektifitas yang didapatkan akan disesuaikan dengan kriteria sebagai berikut :

Tabel 2. Klasifikasi Efektifitas

\begin{tabular}{|c|c|}
\hline Rentang Skor & Klasifikasi \\
\hline $\bar{E}>4,2$ & Sangat Efektif \\
\hline $3,4<\bar{E} \leq 4,2$ & Efektif \\
\hline $2,6<\bar{E} \leq 3,4$ & Cukup Efektif \\
\hline $1,8<\bar{E} \leq 2,6$ & Kurang Efektif \\
\hline $\bar{E} \leq 1,8$ & Tidak Efektif \\
\hline
\end{tabular}

Hasil dari skor rata-rata efektifitas yang diperoleh disesuaikan dengan kriteria sebagai berikut :

1. Jika LKPD dikategorikan sangat efektif berarti LKPD sangat mampu meningkatkan aktivitas, respon dan hasil belajar peserta didik.

2. Jika LKPD dikategorikan efektif berarti LKPD mampu meningkatkan aktivitas, respon dan hasil belajar peserta didik.

3. Jika LKPD dikategorikan cukup efektif berarti LKPD mampu meningkatkan aktivitas, respon dan hasil belajar peserta didik dan sedikit perbaikan.

4. Jika LKPD dikategorikan kurang efektif berarti LKPD kurang mampu meningkatkan aktivitas, respon dan hasil belajar peserta didik danbanyak perbaikan.
5. Jika LKPD dikategorikan tidak efektif berarti LKPD tidak mampu meningkatkan aktivitas, respon dan hasil belajar peserta didik dan perlu pergantian.

\section{HASIL DAN PEMBAHASAN}

Setelah melakukan serangkaian langkah penelitian berdasarkan model ADDIE, pada langkah implementation (implementasi) dilakukan uji keefektifan pada kelas VIII E SMP Negeri 15 Kota Bengkulu untuk melihat efektifitas LKPD berbasis realistic mathematics education dan pendidikan karakter pada materi bangun ruang sisi datar. Keefektifan LKPD dilihat dari hasil analisis lembar pengamatan peserta didik, lembar pengamatan pendidik, angket respon peserta didik serta hasil belajar peserta didik. . Uji ini dilakukan terhadap 28 orang peserta didik di kelas VIII E SMP Negeri 15 Kota Bengkulu selama 7 kali pertemuan dengan 6 kali pertemuan untuk pembelajaran menggunakan LKPD dan 1 kali pertemuan untuk mengerjakan THB. Dalam penelitian ini, peneliti bertindak sebagai pengajar.

\section{Aktivitas Peserta Didik}

Skor rata-rata aktivitas peserta didik pada setiap butir pertanyaan di lembar observasi aktivitas peserta didik dalam enam kali pertemuan disajikan pada tabel berikut.

Tabel 3. Skor rata-rata aktivitas peserta didik

\begin{tabular}{|c|c|c|}
\hline LKPD Ke- & $\begin{array}{c}\text { Skor } \\
\text { rata-rata }\end{array}$ & Kriteria \\
\hline 1 & 3,92 & Efektif \\
\hline 2 & 4,23 & Sangat efektif \\
\hline 3 & 4,65 & Sangat efektif \\
\hline 4 & 4,27 & Sangat efektif \\
\hline 5 & 4,85 & Sangat efektif \\
\hline 6 & 4,96 & Sangat efektif \\
\hline $\begin{array}{c}\text { Jumlah skor } \\
\text { rata-rata }\end{array}$ & 4,48 & Sangat efektif \\
\hline
\end{tabular}

Dari tabel di atas untuk skor keseluruhan pada aktivitas peserta didik dari LKPD ke 1 sampai LKPD ke 6 diperoleh skor rata-rata 4,48 dengan kriteria "sangat efektif". 


\section{a. Aktivitas peserta didik dalam realistic mathematics education}

Akivitas pertama adalah memahami masalah kontekstual dimana aktivitas ini sesuai dengan karakteristik pertama RME yaitu penggunaan konteks. Penggunaan konteks yang dimaksud adalah memberikan masalah realistik yang berada disekitar atau dikehidupan seharihari peserta didik dalam bentuk gambar atau benda-benda yang sering ditemui oleh peserta didik. Penggunaan konteks diberikan sesuai situasi atau keadaan yang ada disekitar peserta didik dengan tujuan agar peserta didik dapat merasakan manfaat mempelajari materi tersebut. Aktivitas ini berdasarkan penilaian dari pengamat pada lembar pengamatan aktivitas peserta didik. Aktivitas ini mendapatkan skor rata-rata 4,75. Artinya, secara keseluruhan peserta didik sudah mampu memahami masalah kontekstual yang disajikan pada LKPD dengan sangat baik.

Aktivitas kedua yaitu menyelesaikan masalah kontekstual untuk menemukan konsep. Kegiatan menemukan konsep menyesuaikan dengan karakteristik penggunaan model serta prinsip penemuan kembali secara terbimbing melalui matematisasi progresif (guided reinvention through progressive mathematizing). Penggunan model yang dimaksud adalah sebuah alat yang digunakan sebagai jembatan peserta didik untuk menemukan pengetahuan berupa konsep. Hal ini sesuai dengan pendapat Treffers dalam Wijaya (2012) menyatakan bahwa penggunaan model berfungsi sebagai jembatan dari pengetahuan dan matematika tingkat konkret menuju pengetahuan matematika tingkat formal. Skor rata-rata pada aktivitas ini adalah 4,5 dengan kriteria sangat setuju. Artinya peserta didik dinilai sudah mampu mengolah informasi dengan sangat baik.

Karakteristik interaktivitas terjadi ketika peserta didik membandingkan dan mendiskusikan hasil kerja dan gagasan mereka didepan kelas. Aktivitas membandingkan dan mendiskusikan jawaban ini memperoleh skor rata-rata 4,42, artinya peserta didik dinilai mampu bekerjasama dalam kelompoknya untuk mendiskusikan jawaban.

Aktivitas selanjutnya adalah menarik kesimpulan. Kesimpulan didapatkan dari hasil kegiatan memahami masalah kontekstual dan menyelesaikan masalah kontekstual. Aktivitas ini mendapatkan skor rata-rata 4,58, artinya peserta didik dinilai sudah mampu menarik kesimpulan dengan sangat baik dari kegiatan yang mereka lakukan.

\section{b. Aktivitas peserta didik dalam pendidikan karakter}

LKPD dirancang sedemikian rupa menyesuaikan dengan langkah-langkah pembentukan karakter. Berikut ini adalah salah satu contoh hasil kerja peserta didik tentang materi pendidikan karakter yang diberikan ketika proses pembelajaran menggunakan LKPD.

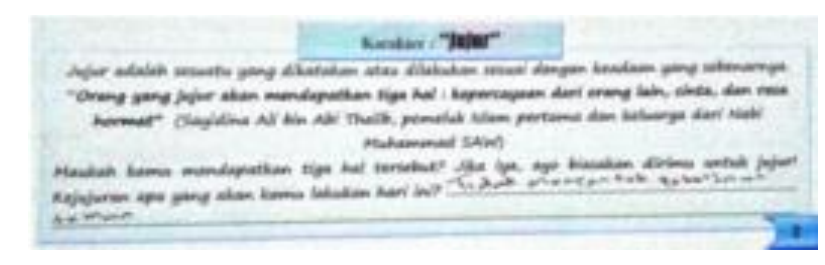

Gambar 3. Hasil kerja peserta didik dalam pendidikan karakter

Dari hasil pengerjaan peserta didik diatas, dapat dilihat bahwa peserta didik sudah dapat membedakan nilai-nilai hakikat kebenaran berupa baik atau buruk. Ini sesuai dengan tahapan pendidikan karakter. Damayanti (2014: 10) menyatakan bahwa pendidikan karakter melalui tahapan pada usia 9 sampai 12 tahun pendidikan karakter yang ditanamkan berupa nilai-nilai hakikat kebenaran berupa baik atau buruk.

Pada aktivitas memahami masalah kontekstual dan menyelesaikan masalah kontekstual, terdapat keterkaitan antara pendekatan realistic mathematics education dengan pendidikan karakter yang dibangun yaitu pendidikan karakter jujur, kerja keras, rasa ingin tahu dan disiplin. Karakter jujur terdapat pada pernyataan keenam dan ketujuh. Pendidikan karakter jujur terlihat ketika peserta

Selli, Della, Agus

Efektifitas Lembar Kerja Peserta Didik Berbasis Realistic Mathematics Education dan Pendidikan Karakter Pada Materi Bangun Ruang Sisi Datar 
didik menyelesaikan masalah kontekstual yang disajikan pada LKPD. Peserta didik tidak dianjurkan untuk melihat hasil kerja kelompok lain dengan tujuan melatih kejujuran pada diri peserta didik. Selanjutnya pada aktivitas menyelesaikan masalah kontekstual dari judul materi unsur-unsur kubus dan balok, peserta didik menggambar kubus dan balok dan memberi nama berdasarkan keinginan kelompok mereka sendiri tanpa harus melihat hasil kerja kelompok lain. Secara keseluruhan, peserta didik sudah menerapkan karakter tidak menyontek. Aktivitas ini mendapatkan skor rata-rata 4,17 dengan kriteria "setuju".

Dalam proses membandingkan dan mendiskusikan jawaban, peserta didik dituntun untuk dapat mengemukakan pendapatnya tanpa ragu walaupun pendapat dari hasil kerja mereka belum tentu benar. Hal ini menunjukkan bahwa peserta didik bekerja berdasarkan kemampuan mereka sendiri dan tidak menyontek ke kelompok lain. Dari hasil pengamatan, sekitar 19 - 24 orang peserta didik atau $61 \%-80 \%$ peserta didik sudah dapat mengemukakan pendapatnya tanpa ragu. Aktivitas ini mendapatkan skor rata-rata 3,92 dengan kategori "setuju".

Kegiatan pada aktivitas menyelesaikan masalah kontekstual melatih peserta didik untuk bekerja keras. Peserta didik harus berupaya sungguh sungguh dan pantang menyerah untuk menemukan sendiri konsep atau hasil pada aktivitas tersebut. Aktivitas ini mendapatkan skor rata-rata 4,42. Artinya sebagian besar peserta didik sudah berupaya dengan sungguh-sungguh untuk menyelesaikan permasalahan yang ada pada LKPD.

Peserta didik dituntut untuk menyelesaikan setiap permasalahan dalam jangka waktu yang telah ditetapkan pada LKPD dan menyelesaikan permasalahan sesuai dengan langkah-langkah yang ada pada LKPD. Secara keseluruhan, peserta didik sudah melakukan kegiatan pembelajaran sesuai dengan langkahlangkah kegiatan pada LKPD dengan skor ratarata 5. Selain itu, peserta didik juga diminta untuk fokus dan tidak ribut saat berdiskusi.
Pernyataan kesepuluh mendapatkan skor ratarata 4,25 , artinya sebagian besar peserta didik sudah menerapkan karakter ini dengan baik.

Dalam menyelesaikan setiap permasalahan, peserta didik dibimbing untuk membaca beberapa informasi yang disajikan pada setiap LKPD. Informasi-informasi yang disajikan berisi petunjuk-petunjuk agar peserta didik mampu menyelesaikan permasalahan yang ada. Setelah itu, peserta didik diminta untuk menuliskan minimal tiga pertanyaan berkaitan dengan materi yang dibahas dan bertanya kepada guru atau temannya apabila mengalami kesulitan. Peserta didik diharapkan dapat antusias dalam mencari jawaban sebagai bentuk rasa ingin tahu mereka. Aktivitas ini mendapatkan skor rata-rata 4,5 , artinya peserta didik sudah antusias dalam mencari jawaban untuk menyelesaikan permasalahan pada LKPD.

\section{Aktivitas Pendidik}

Analisis aktivitas yang sama dilakukan juga untuk melihat aktivitas pendidik dalam mengelola pembelajaran di dalam kelas. Skor rata-rata aktivitas pendidik dalam enam pertemuan disajikan pada tabel berikut.

Tabel 4. Skor rata-rata aktivitas pendidik

\begin{tabular}{|c|c|c|}
\hline LKPD Ke- & $\begin{array}{c}\text { Skor } \\
\text { rata-rata }\end{array}$ & Kriteria \\
\hline 1 & 4,5 & Sangat Setuju \\
\hline 2 & 4,75 & Sangat Setuju \\
\hline 3 & 4,83 & Sangat Setuju \\
\hline 4 & 4,42 & Sangat Setuju \\
\hline 5 & 4,88 & Sangat Setuju \\
\hline 6 & 4,88 & Sangat Setuju \\
\hline $\begin{array}{c}\text { Jumlah skor } \\
\text { rata-rata }\end{array}$ & 4,71 & Sangat Efektif \\
\hline
\end{tabular}

Dapat dilihat pada tabel di atas bahwa untuk skor keseluruhan pada aktivitas pendidik dari LKPD ke 1 sampai LKPD ke 6 diperoleh skor rata-rata 4,71 dengan memenuhi kriteria efektif.

Pada tahap pendahuluan, pengamat mengamati aktivitas dalam pendidik dalam menyampaikan tujuan pembelajaran yang sesuai dengan RPP, kegiatan pendidik dalam memberikan apersepsi kepada peserta didik, 
kegiatan pendidik dalam memotivasi semangat belajar peserta didik, serta kegiatan pendidik dalam mengelompokkan peserta didik dalam proses pembelajaran.

Pengamat juga memperhatikan kegiatan pendidik dalam memberikan support dan membimbing peserta didik yang mengalami kesulitan dalam megerjakan LKPD, mengontrol kerja peserta didik dalam kelompok, memberikan kesempatan kepada peserta didik untuk melakukan kegiatan sesuai dengan urutan pada LKPD, serta membimbing peserta didik untuk menemukan konsep pada masalah yang disajikan. Proses bimbingan yang dilakukan oleh pendidik seperti mendatangi ke meja-meja peserta didik yang mengalami kesulitan, kemudian meminta peserta didik untuk membaca ulang masalah yang disajikan. Jika peserta didik masih belum mengerti, maka pendidik menjelaskan ulang masalah di depan kelas menggunakan bahasa yang sederhana dan mampu dipahami oleh peserta didik.

Pada tahap membandingkan dan mendiskusikan jawaban, aktivitas pendidik yang diamati berupa memperhatikan proses presentasi peserta didik, menjelaskan, dan mengamati perilaku peserta didik serta mengarahkan peserta didik untuk mampu mendapatkan jawaban yang diinginkan. Pada tahap menyimpulkan, pengamat mengamati kegiatan pendidik dalam membimbing peserta didik untuk dapat menyimpulkan materi dalam proses pembelajaran yang sedang dilakukan.

Dari hasil lembar pengamatan diketahui bahwa aktivitas pendidik dalam proses pembelajaran pada keenam LKPD berada dalam kriteria sangat efektif dengan skor ratarata 4,71 .

\section{Respon Peserta Didik}

Skor rata-rata respon peserta didik diperoleh dengan menjumlahkan skor rata-rata respon setiap peserta didik kemudian dibagi banyaknya peserta didik. Skor rata-rata respon siswa adalah 4,23. Rekap penilaian lembar angket respon siswa dapat dilihat pada lampiran 16. Berikut adalah jumlah skor ratarata respon peserta didik setiap LKPD.
Tabel 5. Skor rata-rata respon peserta didik

\begin{tabular}{|c|c|c|}
\hline $\begin{array}{c}\text { LKPD } \\
\text { Ke- }\end{array}$ & $\begin{array}{c}\text { Skor } \\
\text { rata-rata }\end{array}$ & Kriteria \\
\hline 1 & 4,18 & Efektif \\
\hline 2 & 4,05 & Efektif \\
\hline 3 & 4,25 & Sangat Efektif \\
\hline 4 & 4,33 & Sangat Efektif \\
\hline 5 & 4,34 & Sangat Efektif \\
\hline 6 & 4,23 & Sangat Efektif \\
\hline $\begin{array}{c}\text { Skor rata- } \\
\text { rata }\end{array}$ & 4,23 & Sangat Efektif \\
\hline
\end{tabular}

Berdasarkan tabel di atas dapat dilihat untuk skor pada LKPD 1 dan LKPD 2 mendapatkan kriteria efektif, ini disebabkan karena peserta didik belum terbiasa dan masih kesulitan menggunakan LKPD berbasis realistic mathematics education dan pendidikan karakter sehingga peserta didik kurang merespon LKPD yang diberikan dan masih sedikit peserta didik yang memberikan respon sangat setuju. Kemudian pada LKPD ke-3 peserta didik mulai terbiasa menggunakan LKPD, sehingga respon peserta didik mulai meningkat.

Aspek-aspek pertanyaan pada lembar respon peserta didik ini menyangkut penilaian tentang pendekatan realistic mathematics education dan pendidikan karakter yang ada didalam LKPD. Skor yang diperoleh menunjukkan respon peserta didik terhadap pembelajaran yang dilakukan. Semakin besar skor yang diberikan, berarti peserta didik memiliki motivasi dan tanggapan yang baik terhadap pembelajaran dengan menggunakan LKPD. Secara keseluruhan, skor rata-rata respon peserta didik terhadap LKPD yang dikembangkan telah memenuhi kriteria sangat efektif. Hal ini ditunjukkan dari hasil pengisian lembar respon peserta didik yang memperoleh skor rata-rata 4,23.

\section{Hasil Belajar Peserta Didik}

Data hasil belajar setiap peserta didik selama proses pembelajaran diperoleh dari $30 \%$ nilai hasil pengerjaan LKPD dan $70 \%$ nilai hasil tes hasil belajar setelah berakhirnya proses pembelajaran. soal-soal THB yang diberikan terdiri dari 5 soal essay tentang bangun ruang sisi datar. Hasil belajar peserta 
didik dikatakan tuntas jika nilai minimalnya adalah 70 (sesuai dengan standar KKM sekolah).

LKPD yang diterapkan kepada peserta didik pada saat proses pembelajaran mempunyai pengaruh terhadap pemahaman peserta didik pada materi bangun ruang sisi datar sehingga berdampak juga pada hasil belajarnya. Pernyataan ini dapat dilihat dari jawaban-jawaban peserta didik pada lembar tes hasil belajar. Berikut ini adalah salah satu contoh dari jawaban peserta didik pada soal nomor satu di lembar tes hasil belajar.

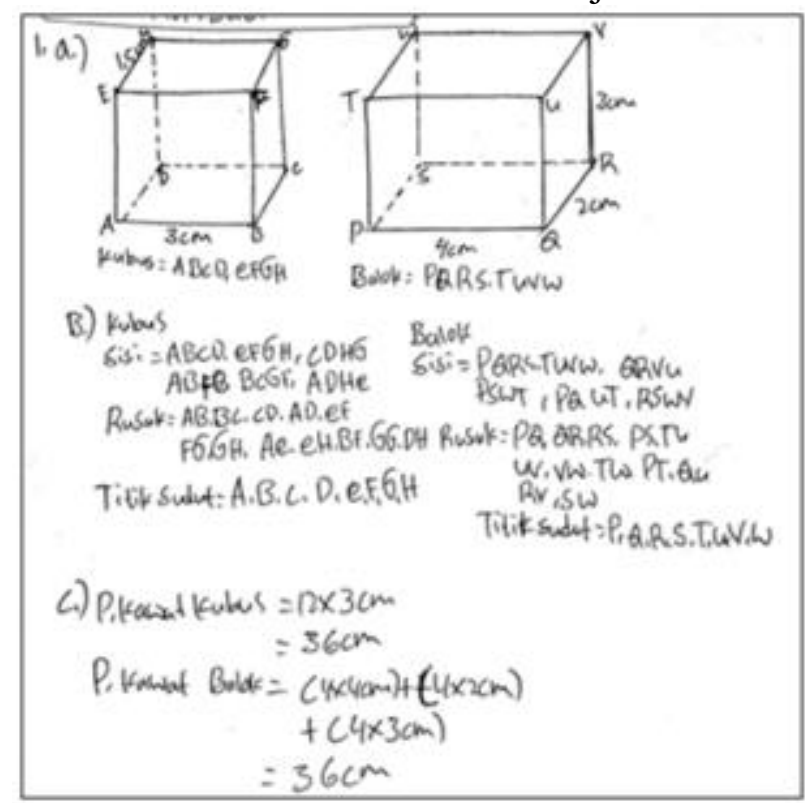

Gambar 4. Hasil Jawaban THB nomor 1 yang tepat

Soal nomor satu merupakan soal yang konsepnya dibahas pada LKPD ke-1 dimana peserta didik dibimbing untuk menemukan konsep dari unsur-unsur kubus dan balok berupa sisi, rusuk, titik sudut, diagonal bidang, diagonal ruang, dan bidang diagonal. Namun untuk soal nomor 1, peserta didik hanya diminta untuk menggambar kubus dan balok serta menentukan sisi, rusuk dan titik sudut berdasarkan nama kubus dan balok yang telah ditentukan. Jawaban peserta didik pada soal nomor satu di atas sesuai dengan konsep yang peserta didik temukan di LKPD ke-1. Peserta didik dapat menggambar serta menentukan sisi, rusuk, dan titik sudut dengan benar. Hal ini cukup memperlihatkan bahwa LKPD 1 mempunyai pengaruh terhadap hasil jawaban peserta didik.

Akan tetapi masih ada peserta didik yang menjawab soal nomor satu dengan tidak tepat. Peserta didik tidak menggambar kubus dan balok dengan rapi dan tidak lengkap seperti tidak menulis ukurannya,serta sisi, rusuk dan titik sudut tidak disebutkan semua. Akibatnya peserta didik tidak memperoleh skor maksimal untuk soal ini. Berikut ini jawaban peserta didik tersebut.

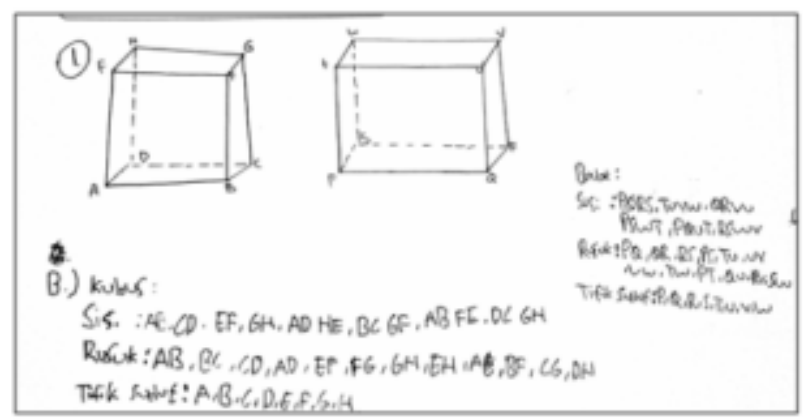

Gambar 4.33 Hasil Jawaban THB nomor 1 yang kurang tepat

Secara keseluruhan peserta didik sudah mampu menyebutkan unsur-unsur kubus dan balok. Hanya saja kebanyakan peserta didik tidak lengkap menyebutkan unsur-unsurnya dan tidak tepat dalam menggambar kubus dan balok, sehingga berdampak pada berkurangnya skor yang diperoleh. Skor total untuk soal nomor 1 adalah 29. Rata-rata skor dari peserta didik yang menjawab soal nomor 1 adalah 24,25. 3 orang peserta didik sudah mampu menjawab soal dengan benar dan tepat serta memperoleh skor maksimal. Sebagian sudah menjawab soal ini dengan benar, tetapi kurang tepat. Skor minimal yang diperoleh pada soal nomor satu adalah 15. Hal ini membuktikan bahwa hampir keseluruhan dari peserta didik sudah memahami materi unsur-unsur kubus dan balok tetapi memiliki keterampilan yang rendah dalam menggambar kubus dan balok dengan menggunakan LKPD.

Soal nomor dua merupakan soal yang konsepnya dibahas pada proses pembelajaran dengan menggunakan LKPD ke-2 dengan modifikasi. Pada LKPD ke-2 peserta didik dibimbing untuk menemukan rumus luas permukaan kubus dan balok. Untuk soal nomor

Selli, Della, Agus

Efektifitas Lembar Kerja Peserta Didik Berbasis Realistic Mathematics Education dan Pendidikan Karakter Pada Materi Bangun Ruang Sisi Datar 
2, peserta didik diminta untuk mencari luas triplek untuk kotak tanpa tutup serta mencari biaya yang diperlukan. Rata-rata peserta didik mampu menyelesaikan pertanyaan ini dengan tepat. Tetapi peserta didik kebanyakan tidak menuliskan diketahui dan ditanya pada soal nomor dua, tidak menyertakan satuan ukurannya, dan salah menghitung sehingga skor yang diperoleh tidak maksimal. Rata-rata skor yang diperoleh peserta didik untuk soal nomor 2 adalah 10,14. Skor maksimal yang diperoleh peserta didik untuk soal nomor dua adalah 12 dan skor minimal adalah 7 . Hal ini membuktikan bahwa hampir keseluruhan dari peserta didik dapat memahami konsep luas permukaan kubus dan balok dengan menggunakan LKPD. Berikut hasil pengerjaan soal nomor 2 .

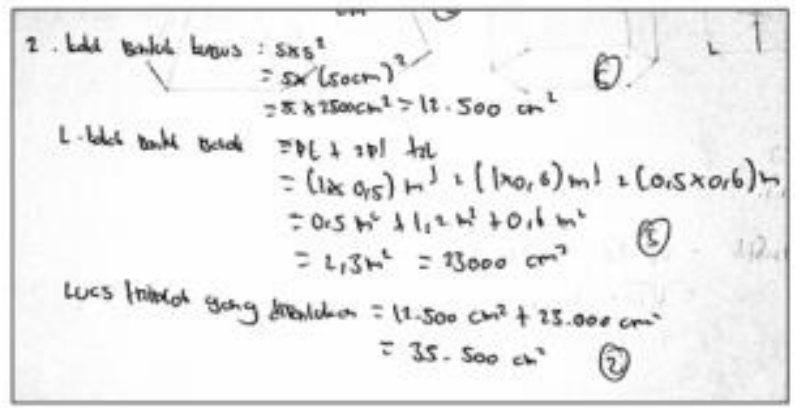

Gambar 5 Hasil Jawaban THB nomor 2

Soal nomor tiga merupakan soal yang dibahas konsepnya pada proses pembelajaran dengan menggunakan LKPD ke-3 dimana peserta didik diminta untuk menghitung banyak air yang dibutuhkan untuk mengisi penuh bak berupa gabungan antara kubus dan balok serta menentukan waktu yang diperlukan untuk mengisi penuh bak tersebut. Jawaban peserta didik pada soal nomor 3 sesuai dengan konsep yang peserta didik temukan di LKPD ke-3.

Dari keseluruhan jumlah peserta didik yang mengikuti THB untuk nomor 3, hampir seluruh peserta didik mampu menjawab soal nomor 3 dengan benar. 1 orang peserta didik tidak menjawab sama sekali. Rata-rata skor yang diperoleh untuk soal nomor 3 adalah 10,78. Hal ini membuktikan bahwa hampir keseluruhan dari peserta didik dapat memahami konsep volume kubus dan balok dengan menggunakan LKPD. Berikut hasil jawaban peserta didik.

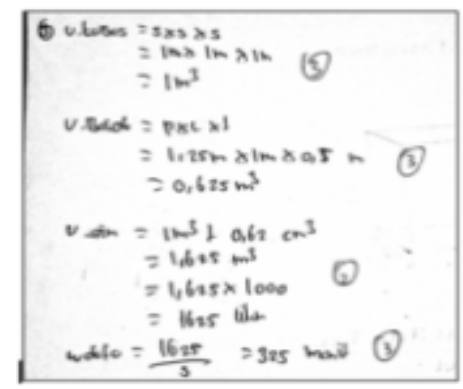

Gambar 6 Hasil Jawaban THB nomor 3

Soal nomor empat merupakan soal yang konsepnya dibahas pada proses pembelajaran dengan menggunakan LKPD ke-4 dengan modifikasi. Pada LKPD ke-4 peserta didik dibimbing untuk menemukan konsep dari unsur-unsur prisma dan limas berupa sisi, rusuk, titik sudut, diagonal bidang, diagonal ruang, dan bidang diagonal. Namun untuk soal nomor 4 , peserta didik hanya diminta untuk menentukan bentuk bangun datar dari sisi prisma dan limas dalam hal ini dinamakan potongan-potongan yang akan dibentuk, banyak potongan, serta gambar alat peraga yang akan dibuat. Untuk soal nomor 4, kebanyakan peserta didik tidak mampu menyelesaikan soal nomor 4 bagian (c), yaitu mengambar prisma dan limas. Sama halnya seperti soal nomor 1, peserta didik kebanyakan belum mampu menggambar kubus, balok, prisma dan limas dengan benar. Hal ini menunjukkan bahwa peserta didik memiliki keterampilan yang rendah dalam hal menggambar. Selain itu, faktor ini juga disebabkan karena peserta didik tidak siap dalam peralatan berupa penggaris. Dari keseluruhan jumlah peserta didik yang mengikuti THB untuk nomor 4, rata-rata skor yang diperoleh adalah 12,93 dari skor maksimal 18. Berikut ini jawaban peserta didik untuk soal nomor 4 dalam menggambar prisma dan limas. 


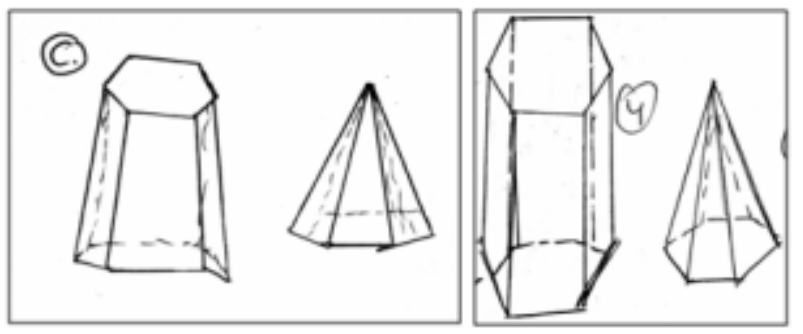

Gambar 7. Hasil Jawaban THB nomor 4 menggambar prisma dan limas

Soal nomor lima merupakan soal yang konsepnya dibahas pada proses pembelajaran dengan menggunakan LKPD ke-5 dengan judul luas permukaan prisma dan limas digabungkan dengan LKPD ke-6 dengan judul materi volume prisma dan limas. Penerapan konsep untuk LKPD ke-5 digunakan pada soal bagian (a) dan bagian (b) sedangkan untuk LKPD ke-6 penerapannya digunakan pada soal bagian (c). Berikut ini jawaban peserta didik untuk soal nomor 5.

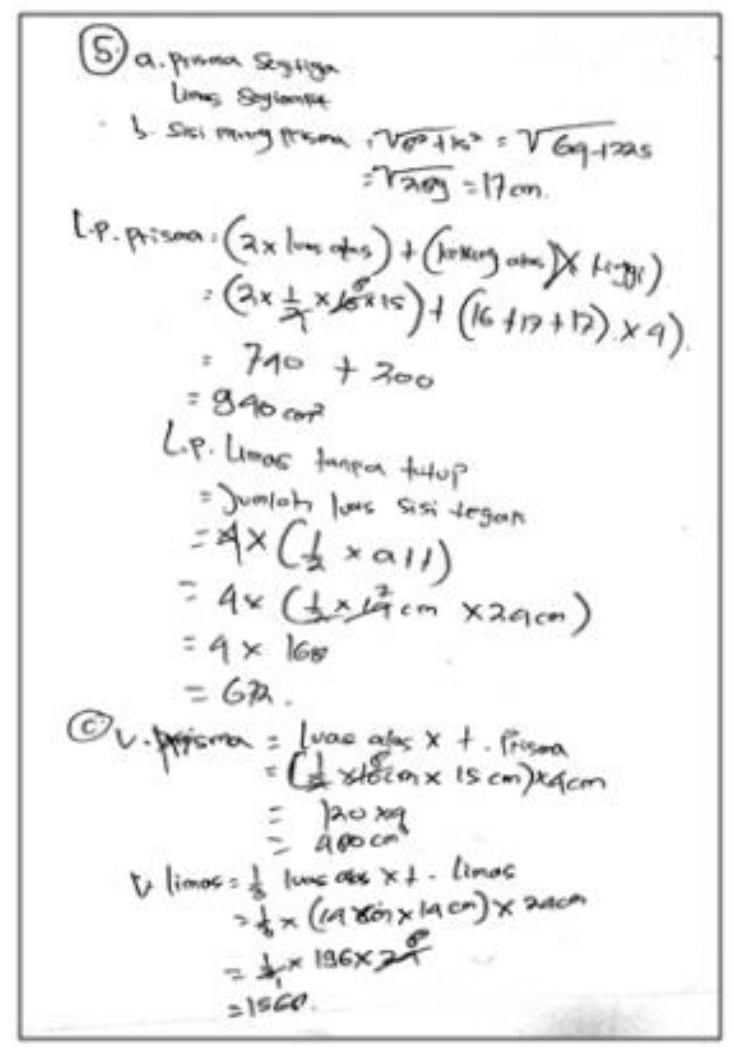

Gambar 8. Hasil Jawaban THB nomor 5

Dari jawaban peserta didik diperoleh bahwa peserta didik kebanyakan salah menjawab untuk soal bagian (b). Mereka tidak menggunakan rumus phytagoras untuk mencari panjang salah satu sisi yang belum diketahui.
Sehingga untuk soal bagian ini, tidak ada peserta didik yang memperoleh skor maksimal. Rata-rata skor untuk soal nomor 5 adalah 14,24 dari skor maksimal 26. Faktor lain yang menyebabkan peserta didik tidak memperoleh skor maksimal adalah kurangnya waktu bagi peserta didik untuk menyelesaikan soal.

Hasil kerja peserta didik pada lembar tes hasil belajar memperlihatkan bahwa LKPD yang dikembangkan dapat diterapkan dalam proses pembelajaran sehingga mempunyai pengaruh yang baik terhadap pemahaman pesera didik. Akan tetapi masih ada beberapa peserta didik yang nilai tes hasil belajarnya masih dibawah ketuntasan minimal. Hasil belajar setiap peserta didik diperoleh dari $30 \%$ nilai LKPD dan $70 \%$ nilai tes hasil belajar. Hasil belajar peserta didik dikatakan tuntas jika minimal nilainya 70 disesuaikan dengan KKM dari sekolah yang bersangkutan. Berdasarkan hasil belajar peserta didik yang diperoleh 24 peserta didik yang tuntas dari 4 peserta didik yang belum tuntas dengan persentase jumlah peserta didik yang tuntas sebesar $85,71 \%$. Menurut Widoyoko (2009: 242) persentase ketuntasan belajar di atas nilai 80 berkategori "sangat baik" dengan skor 5. Ini membuktikan bahwa peserta didik sudah mampu menerapkan konsep yang didapat pada proses pembelajaran dengan menggunakan LKPD sehingga dapat menyelesaikan lembar THB yang diberikan.

Dari hasil lembar pengamatan aktivitas peserta didik dan pendidik, respon peserta didik, dan hasil belajar peserta didik diperoleh skor rata-rata efektifitas yaitu 4,32 dengan kriteria "sangat efektif".

Dari hasil penelitian, diperoleh bahwa nilai rata-rata pengerjaan LKPD 28 peserta didik adalah 82 dan nilai rata-rata THB adalah 70,89 . Nilai rata-rata LKPD dan THB masing-masing peserta didik tersaji dalam grafik berikut ini.

Selli, Della, Agus

Efektifitas Lembar Kerja Peserta Didik Berbasis Realistic Mathematics Education dan Pendidikan Karakter Pada Materi Bangun Ruang Sisi Datar 


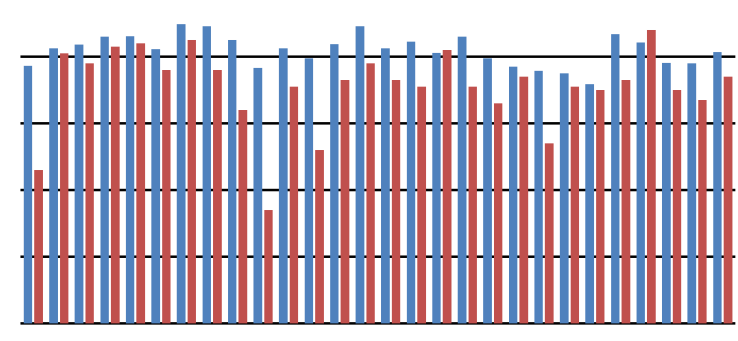

nata-rata LKPD

Rata-rata THB

Gambar 9. Grafik rata-rata LKPD dan THB

Dari grafik di atas, rata-rata nilai pengerjaan LKPD dan nilai THB peserta didik tidak jauh berbeda. Secara keseluruhan ratarata nilai pengerjaan LKPD sudah tuntas dan untuk nilai THB hanya 7 orang peserta didik yang nilainya belum tuntas. Skor rata-rata hasil belajar 28 orang peserta didik yang diperoleh dari $30 \%$ pengerjaan LKPD dan $70 \%$ pengerjaan THB adalah 74. Jika dikonversi maka hasilnya adalah 4,18. Hasil belajar peserta didik disajikan dalam bentuk tabel dibawah ini.

Tabel 6. Hasil belajar peserta didik

\begin{tabular}{|l|c|c|}
\hline $\begin{array}{c}\text { Kriteria hasil } \\
\text { belajar }\end{array}$ & $\begin{array}{c}\text { Jumlah } \\
\text { peserta didik }\end{array}$ & $\begin{array}{c}\text { Persentase } \\
(\mathbf{\%})\end{array}$ \\
\hline Tuntas & 24 & 85,71 \\
\hline Tidak Tuntas & 4 & 14,29 \\
\hline
\end{tabular}

Tabel di atas menunjukkan bahwa sebanyak 24 peserta didik tuntas secara klasikal dan memenuhi kriteria ketuntasan secara klasikal di atas $80 \%$. Menurut Widoyoko (2009: 242) persentase ketuntasan belajar di atas nilai 80 berkategori "sangat baik" dengan skor 5. Ini membuktikan bahwa peserta didik sudah mampu menerapkan konsep yang didapat pada proses pembelajaran dengan menggunakan LKPD sehingga dapat menyelesaikan setiap soal pada lembar THB yang diberikan. Sehingga dapat dikatakan bahwa peserta didik telah mencapai kompetensi yang telah ditentukan. Hasil uji efektivitas memberikan skor rata-rata efektivitas yaitu 4,32. Skor rata-rata efektivitas menggunakan rumus berikut ini.

$$
\begin{gathered}
\bar{E}=\frac{(\overline{A P D} \times 15 \%)+(\overline{A P} \times 15 \%)+(\bar{R} \times 30 \%)+(\bar{H} \times 40 \%)}{100 \%} \\
\bar{E}=\frac{(4,48 \times 15 \%)+(4,71 \times 15 \%)+(4,23 \times 30 \%)+(4,18 \times 40 \%)}{100 \%} \\
\bar{E}=4,32
\end{gathered}
$$

Berdasarkan data yang diperoleh terlihat bahwa efektivitas LKPD dalam kategori sangat efektif. Hal ini menunjukkan bahwa LKPD layak digunakan dan dapat memberikan manfaat pada proses pembelajaran. Manfaat tersebut adalah mampu meningkatkan aktivitas dalam kegiatan belajar mengajar, respon, dan hasil belajar peserta didik pada materi bangun ruang sisi datar.

\section{PENUTUP}

\section{A. Simpulan}

Dari hasil penelitian pengembangan Lembar Kerja Peserta Didik (LKPD) berbasis realistic mathematics education dan pendidikan karakter pada materi bangun ruang sisi datar dengan model pengembangan ADDIE diperoleh kesimpulan sebagai berikut.

LKPD berbasis realistic mathematics education dan Pendidikan Karakter pada materi bangun ruang sisi datar termasuk dalam kategori efektif dengan skor rata-rata 4,32 karena :

1. Aktivitas peserta didik dalam kegiatan belajar dalam kriteria sangat efektif dengan skor rata-rata 4,48

2. Aktivitas pendidik dalam kegiatan belajar dalam kriteria sangat efektif dengan skor rata-rata 4,71

3. Respon peserta didik terhadap pembelajaran dalam kriteria sangat efektif dengan skor rata-rata 4,23

4. Hasil belajar peserta didik dalam kriteria sangat efektif berdasarkan olah data nilai LKPD dan tes hasil belajar (THB) dengan skor rata-rata 74 atau jika dikonversi hasilnya adalah 4,18

\section{B. Saran}

Saran-saran yang dapat diberikan penulis sebagai sumbangan pemikiran terhadap

Selli, Della, Agus

Efektifitas Lembar Kerja Peserta Didik Berbasis Realistic Mathematics Education dan Pendidikan Karakter Pada Materi Bangun Ruang Sisi Datar 
pengembangan perangkat pembelajaran adalah sebagai berikut.

1. Bahasa yang digunakan untuk pengembangan LKPD sebaiknya menggunakan bahasa yang sederhana, tidak menggunakan bahasa yang terlalu rumit, mudah dipahami, dan disesuaikan dengan tingkat pemahaman peserta didik sebagai pengguna LKPD agar mudah digunakan.

2. Dalam pengembangan LKPD pembahasan tentang geometri sebaiknya perlu ditambah kegiatan untuk melatih keterampilan peserta didik dalam menggambar.

3. Pengembangan LKPD berbasis pendidikan karakter sebaiknya pendidikan karakternya langsung terintegrasi di dalam materi yang akan diajarkan atau bisa dimuat dalam masalah-masalah yang disajikan agar peserta didik benar-benar dapat menanamkan karakter-karakter tersebut dalam dirinya.

\section{DAFTAR PUSTAKA}

Arikunto, Suharsimi. 2013. Dasar-dasar Evaluasi Pendidikan. Jakarta: Bumi Aksara.
Branch, Robert Maribe. 2009. Instructional Design : The ADDIE Approach. New York: Spinger.

Damayanti, Deni. 2014. Panduan Implementasi Pendidikan Karakter di Sekolah. Yogyakarta : Araska.

Desmita. 2009. Psikologi Perkembangan Peserta Didik. Bandung: Remaja Rosdakarya.

Hadi, Sutarto. 2017. Pendidikan Matematika Realistik : Teori, Pengembangan, dan Implementasinya. Jakarta: PT RajaGrafindo Persada.

Prastowo, Andi. 2015. Panduan Kreatif Membuat Bahan Ajar Inovatif. Jogjakarta: DIVA Press.

Sudjana. 2005. Metode Statistika. Bandung: Tarsito.

Sugiyono. 2016. Metode Penelitian \& Pengembangan. Bandung: Alfabeta.

Widoyoko, Eko Putro. 2009. Evaluasi Program Pembelajaran. Yogyakarta: Pustaka Pelajar.

Wijaya, Ariyadi. 2012. Pendidikan Matematika Realistik : Suatu Alternatif Pendekatan Pembelajaran Matematika. Yogyakarta: Graha Ilmu. 